\title{
Phenotypic Stability and Correlation for Late Blight Resistance in Advanced Potato Clones Under Field and Controlled Conditions
}

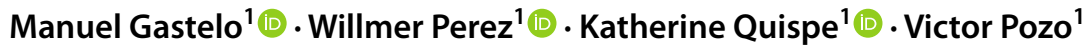

Accepted: 3 January 2022 / Published online: 21 February 2022

(c) The Author(s) 2022

\begin{abstract}
Late blight (LB) is the main potato disease worldwide and one of the most important ways to control it is the use of resistant varieties. Twenty-two potato clones from the B3 breeding population developed by the International Potato Center with high resistance to the disease and two susceptible controls were inoculated with four Peruvian complex isolates (POX67, PPA61, PLL69, and PPI112) of Phytophthora infestans, with complex virulence on potato. Whole plant inoculation assays were carried out under greenhouse and humid chamber conditions in Lima, Peru, and data obtained were correlated with data from field assays carried out in Oxapampa (Pasco), a CIP breeding site in the Peruvian rain forest. High significant correlations $(\alpha=0.01)$ were found in the resistance to LB shown by potato clones, the values of the correlations under greenhouse conditions between the isolates POX67, PPA61, and PLL69 with the resistance in the field were $r=0.93,0.92$ and 0.80 , respectively and under humid chamber conditions were $r=0.94,0.93$ and 0.94 , respectively. Moderate correlations were found between resistance in the field and in the greenhouse $(\mathrm{r}=0.69)$ and the field and in humid chamber conditions $(r=0.77)$ for inoculations with PPI112 isolate. The twenty-two clones tested in this study showed phenotypic stability for $\mathrm{LB}$ resistance according to non-parametric analysis.
\end{abstract}

\section{Resumen}

El tizón tardío (LB) es la principal enfermedad de la papa en el mundo y una de las formas más importantes de controlarlo es el uso de variedades resistentes. Veintidós clones de papa de la población de mejoramiento B3 desarrollada por el Centro Internacional de la Papa (CIP) con alta resistencia a la enfermedad, y dos controles susceptibles se inocularon con cuatro aislamientos complejos peruanos (POX67, PPA61, PLL69 y PPI112) de Phytophthora infestans, con virulencia compleja en papa. Se desarrollaron ensayos de inoculación de plantas enteras en condiciones de invernadero y cámara húmeda en Lima, Perú, y los datos obtenidos se correlacionaron con los datos de los ensayos de campo realizados en Oxapampa (Pasco), un sitio de mejoramiento del CIP en la selva peruana. Se encontraron altas correlaciones significativas $(\alpha=0,01)$ en la resistencia a LB mostrada por clones de papa, los valores de las correlaciones en condiciones de invernadero entre los aislamientos POX67, PPA61 y PLL69 con la resistencia en el campo fueron $r=0,93,0,92$ y 0,80, respectivamente y en condiciones de cámara húmeda fueron $r=0.94,0.93$ y 0.94 , respectivamente. Se encontraron correlaciones moderadas entre la resistencia en el campo y en el invernadero $(r=0.69)$ y el campo y en condiciones de cámara húmeda $(r=0.77)$ para las inoculaciones con el aislamiento PPI112. Los veintidós clones probados en este estudio mostraron estabilidad fenotípica para la resistencia al LB de acuerdo con el análisis no paramétrico.

Keywords Breeding $\cdot$ Pathology $\cdot$ Greenhouse $\cdot$ Humid chamber $\cdot$ Non-parametric stability $\cdot$ AUDPC ranking

\section{Introduction}

Manuel Gastelo

m.gastelo@cgiar.org; mgastelo_b@hotmail.com

1 International Potato Center, Lima 12, Peru
Potato (Solanum tuberosum L.) is the third most consumed crop in the world after rice and wheat (Devaux et al. 2014). Late blight (LB), caused by the oomycete Phytophthora infestans (Mont.) de Bary, is the main disease that affects the potato crop. When it is not controlled in a timely manner, 
it can cause total loss of production (Nutter et al., 1993). One of the forms of control is the use of resistant varieties containing resistance genes derived from Solanum demissum (Black et al. 1953; Malcolmson and Black 1966; Simmonds and Wastie 1987) and other species. There are two types of resistance: a) vertical resistance related to the presence of major resistance genes ( $R$ genes) based on the gene-forgene concept and effective only against some races of the pathogen that carry and express an avirulence allele that is compatible with a $R$ gene in the host, and b) horizontal resistance, also called partial or field resistance, which is not specific to the races of the pathogen. In the field these two types of resistance cannot be easily distinguished (Forbes 2012; Sharma et al. 2013), however, varieties with vertical resistance provide extreme resistance, but are vulnerable to changes in the pathogen population (Flor 1971).

Horizontal resistance is affected by environmental conditions, and it is very important to consider genotype by environment interactions (GxE) in the selection of clones resistant to LB (Umaerus 1994; Forbes et al. 2005). It is important to expose potato clones to complex $P$. infestans isolates under contrasting environments when stability of LB resistance is assessed. The instability of the resistance in some clones to more complex isolates or from different hosts can indicate the presence of major $R$ genes different from those from $S$. demissum (Mihovilovich et al. 2010). The level of change in resistance achieved in one cycle of genetic recombination in breeding populations as well as the negative correlation of lower LB resistance and higher stability indicate that the effect may be due to major $R$ genes (Lotta 2015).

The International Potato Center-CIP has developed a population of clones with high levels of horizontal resistance named B3, over three selection cycles (B3C1, B3C2 and $\mathrm{B} 3 \mathrm{C} 3$ ), which were selected under natural epidemics in the Peruvian rainforest (Oxapampa, at 1,810 masl) (Landeo et al. 1995, 1997). At this CIP breeding site, Avr5 and Avr9 genes are scarce or are in very low frequencies (Villamon et al. 2005; Lindqvist-Kreuze et al. 2010). Thus, it is necessary to evaluate the resistance of these clones under controlled conditions with other races of LB that have Avr9 gene corresponding to $R 9$ resistance gene.

Several studies carried out under controlled conditions and then compared with resistance obtained under field conditions found significant correlations $(r=90)$ for resistance between laboratory and field conditions (Dorrance and Inglis 1997), and for whole plant resistance between greenhouse and field conditions in a study carried out in Nepal (Sharma et al 2013). In a study carried out by Vleeshouwers et al. (1999), comparison of rankings of resistance obtained under field and greenhouse conditions were similar.
Genotype $\mathrm{x}$ environment interactions (GxE) have a very important role in the development of the disease, so it is necessary to identify clones that are stable in their response to different genotypes of $P$. infestans. Phenotypic stability of resistance is very important in the selection of resistant clones. It can be determined through parametric statistical analysis, where the assumption is that the error variances are constant across environments (Neter \& Wasserman 1974), and that can be tested using Bartlett's test (Bartlett 1937).

When there is no homogeneity of variance among environments, it is not possible to analyze the combined experiments with parametric methods. Non-parametric analysis allowed us to overcome the interactions of the environment with the pathogen and the host (Haynes et al. 1998).

Huehn (1990a, b) developed nonparametric stability analysis when homoscedasticity does not exist, which considers the variance or standard deviation of rankings of resistance of a genotype in different environments (Nasar and Huhn 1987). A program in SAS for this nonparametric phenotypic stability analysis was developed (Lu 1995), and several researchers have been able to make better selections of genotypes resistant to LB using this type of analysis (Leon and Becker 1988).

In another study carried out over six years in two endemic localities for LB in Peru, where the clonal lineage EC-1 is present (Perez et al., 2009), 70 of 172 potato clones tested from the $\mathrm{B} 3 \mathrm{C} 2$ population showed a coefficient of variability less than 0.5 for resistance through years and localities, and they were considered as phenotypically stable (LindqvistKreuze et al. 2014). The authors mentioned that stability is not equal to durability of resistance (Lindqvist-Kreuze et al. 2014).

Clonal lineage is a clonal descendent from one unique individual; it dominates a geographic region until a more fit individual displaces it ( $\mathrm{Li}$ et al, 2012). Identification of clonal lineages has been carried out through different molecular technics as RFLP, multilocus genotyping, AFLP or simple sequence repeats (SSR), next-generation sequencing, mitochondrial genome sequencing, transcriptome sequencing, and genotyping by sequencing. Clonal lineage EC-1 of $P$. infestans is present in Ecuador and Colombia (Cardenas et al., 2011; Delgado et al., 2013), and is also the dominating lineage in Peru (Lindqvist-Kreuze et al, 2020).

The objectives of this study were: 1) to determine correlations of resistance to LB in 22 potato clones under natural field conditions (where the presence of the $A v r 9$ is scarce are or in very low frequency) with resistance to three complex isolates of $P$. infestans with Avr 9 , under greenhouse and humid chamber conditions, and 2) to determine phenotypic stability of the resistance to LB under field, greenhouse and humidity chamber conditions. 


\section{Materials and Methods}

In this study, we evaluated twenty-two clones from the B3 population developed by the CIP breeding program and two popular Peruvian susceptible varieties, Canchan and Yungay, as controls (Table 1). These potato clones have high levels of resistance to LB; they could have some unknown $R$ genes from other species of Solanum in addition to the R8 gene from Solanum demisum (Jiang et al. 2018). Twenty clones are from the cycle 3 (B3C3) and two clones from the cycle 1 (B3C1) populations.

In the 2018-2019 growing season, a field experiment was planted under endemic conditions in the Peruvian rainforest (Oxapampa, Peru, 1814 masl, 10³4'48" S, $75^{\circ} 24^{\prime} 0^{\prime \prime}$ with relative humidity of more than $80 \%$, annual rainfall of more than $2000 \mathrm{~mm}$ and temperature of 10 to $22^{\circ}$ C.), where $A v r 5$ and $A v r 9$ genes probably are not present or are present in very low frequency (Villamon et al 2005; Lindqvist-Kreuze et al 2010). The predominant clonal lineage in the zone is EC- 1 and a representative is isolate POX067 (Table 2). A randomized complete block design with three replicates of 10 plants each was used in this experiment. Six visual severity readings were registered beginning 55 days after planting and continuing at seven days intervals in each plot. Based on this information, area under the progress curve of the disease (AUDPC) and scale of susceptibility to late blight
Table 1 Potato clones used in the phenotypic stability and correlation study

\begin{tabular}{|c|c|c|c|c|c|}
\hline$\#$ & Clone & Group & Female Parent & Male Parent & $\begin{array}{l}\text { Resistance to } \\
\text { Late Blight* }\end{array}$ \\
\hline 1 & CIP 308427.194 & B3C3 & CIP 395017.229 & CIP 395011.2 & Resistant \\
\hline 2 & CIP 308436.173 & B3C3 & CIP 395111.13 & CIP 395011.2 & Resistant \\
\hline 3 & CIP 308436.245 & B3C3 & CIP 395111.13 & CIP 395011.2 & Resistant \\
\hline 4 & CIP 308441.148 & B3C3 & CIP 395114.5 & CIP 396240.2 & Resistant \\
\hline 5 & CIP 308475.174 & B3C3 & CIP 395037.107 & CIP 396240.2 & Resistant \\
\hline 6 & CIP 308478.122 & B3C3 & CIP 395096.2 & CIP 396264.14 & Resistant \\
\hline 7 & CIP 308481.302 & B3C3 & CIP 395109.34 & CIP 395017.229 & Resistant \\
\hline 8 & CIP 308482.163 & B3C3 & CIP 395109.34 & CIP 396038.107 & Resistant \\
\hline 9 & CIP 308487.163 & B3C3 & CIP 395112.32 & CIP 396264.14 & Resistant \\
\hline 10 & CIP 308487.390 & B3C3 & CIP 395112.32 & CIP 396264.14 & Resistant \\
\hline 11 & CIP 308488.213 & B3C3 & CIP 395112,36 & CIP 396004,337 & Resistant \\
\hline 12 & CIP 308489.286 & B3C3 & CIP 395112.36 & CIP 396029.205 & Resistant \\
\hline 13 & CIP 308490.407 & B3C3 & CIP 395112.36 & CIP 396263.8 & Resistant \\
\hline 14 & CIP 308493.164 & B3C3 & CIP 395117.3 & CIP 395096.3 & Resistant \\
\hline 15 & CIP 308494.368 & $\mathrm{~B} 3 \mathrm{C} 3$ & CIP 395123.6 & CIP 396240.23 & Resistant \\
\hline 16 & CIP 308495.329 & B3C3 & CIP 395179.21 & CIP 395017.227 & Resistant \\
\hline 17 & CIP 308498.280 & B3C3 & CIP 396004.263 & CIP 395017.229 & Resistant \\
\hline 18 & CIP 308499.112 & B3C3 & CIP 396004.263 & CIP 396038.107 & Resistant \\
\hline 19 & CIP 308503.312 & B3C3 & CIP 396009.207 & CIP 395017.242 & Resistant \\
\hline 20 & CIP 308519.110 & B3C3 & CIP 396046.105 & CIP 396017.227 & Resistant \\
\hline 21 & CIP 393371.58 & $\mathrm{~B} 3 \mathrm{C} 1$ & CIP 387170.16 & CIP 389746.2 & Resistant \\
\hline 22 & CIP 387164.4 & $\mathrm{~B} 3 \mathrm{C} 1$ & CIP 382171.10 & 575049 & Resistant \\
\hline 23 & Yungay & Control & Sequoia $x$ Earline & Huagalina $x$ Renacimiento & Susceptible \\
\hline 24 & Canchan & Control & BL1.2 & Murillo III-80 & Susceptible \\
\hline
\end{tabular}

*Determined by sAUDPC in Oxapampa 2018-2019

\begin{tabular}{lllll}
\hline Isolate & Host & Mating Type & Race & Clonal Lineage \\
\hline PLL69 $* *$ & S. tuberosum & A1 & $1,2,3,4,5,6,7,9,10,11$ & EC-1 \\
POX067 $*$ & S. tuberosum & A1 & $1,2,3,4,5,6,7,10,11$ & EC-1 \\
PPA61 $* *$ & S. tuberosum & A1 & $1,2,3,4,5,6,7,9,10,11$ & EC-1 \\
PPI112 $* *$ & S. huancabambense & A1 & $1,2,3,4,6,7,9,10,11$ & EC-1 \\
\hline
\end{tabular}

*Villamon et al. 2005 **Lindqvist-Kreuze et al. 2010 
(sAUDPC) values, were calculated according to Forbes et al. (2014) and Yuen and Forbes (2009), respectively. Three reaction levels according to susceptibility scale values were assigned: resistant (clones with scale value between 0 to 3 ), moderately resistant (clones with scale value between 3.1 to 6 ) and susceptible (clones with scale value between 6.1 to 9 . A clone is considered resistant when its SAUDPC values are in the respective range for the four isolates.

In the 2019-2020 growing season, two experiments were planted in La Molina, Lima, Peru, under controlled conditions: 1) greenhouse conditions (average temperature $19.63{ }^{\circ} \mathrm{C}$, range $17-24{ }^{\circ} \mathrm{C}$, average relative humidity $92.59 \%$, range $70-99 \%$ ), and 2 ) humidity chamber conditions (average temperature $16.81{ }^{\circ} \mathrm{C}$, range $15-23{ }^{\circ} \mathrm{C}$, and $97 \%$ relative humidity, range $78-100 \%$ ).

Potato clones and controls were inoculated with 4 isolates of P. infestans: POX067, collected in Oxapampa, Pasco at 1810 masl (Villamon et al. 2005; Lindqvist-Kreuze et al. 2010); PLL69 collected in Huamachuco, La Libertad at 3000 masl, 749'36.2" S, 78²'45.89" W; PPA61 collected in Paucartambo, Pasco at 2950 masl, 10 46'28.43" S, 749'17.48" W; and PPI112 collected in Huancabamba, Piura at 1929 masl, 5¹4'22.46" S, 79²6'58.71" W (Lindqvist-Kreuze et al. 2020) (Table 2). Isolates used in this study represent a wide range of genotypes of $P$. infestans and belong to same lineage EC-1, however, all were collected from different places, from different hosts, and had different Multi Locus Genotypes based on SSR (Microsatellite) analysis. This last characteristic is related to adaptation of the pathogen to zones with high pressure of the disease, use of pesticides and capacity for distribution into potato growing areas.

Four plants of each genotype were inoculated with one isolate in each experiment. Each plant was considered as a replication. All genotypes inoculated with the same isolate were separated from other plants inoculated with hermetic plastic barriers which avoided any cross infection. Each plant was sprayed until run- off with $30-60 \mathrm{mml}$ of $3 \times 10^{3}$ sporangia concentration. Plants were inoculated before flowering approximately 40 days after planting. Two severity readings were carried out at 4 and 6 days after inoculation. AUDPC (Forbes et al 2014) and scale of susceptibility to late blight (sAUDPC) (Yuen and Forbes 2009) were calculated based on severity readings. Analyses of variance were run on AUDPC and SAUDPC, where potato clones, pathogen isolates, and environment were considered fixed effects.

Pearson correlation coefficients $(\alpha=0.01)$ (Wang 2013) were used to determine the association between resistance to LB measured through the sAUDPC under controlled conditions and the field. Phenotypic stability for resistance to LB analyzed for three environments (greenhouse, humidity chamber and field) was performed using AUDPC values according to non-parametric stability analysis (Huehn, 1990a, b) and a SAS program developed by Lu (1995). Homoscedasticity was determined through Bartlett's test of homogeneity of variance (Fraser 1992; Bartlett 1937). SAS software, Version 9.4 of the SAS System for Windows was used for statistical analysis.

\section{Results and Discussion}

In the field experiment, analysis of variance for AUDPC, rAUDPC and sAUDPC values showed statistically significant differences $(\alpha=0.01)$ among potato clones tested but not among replications (Table 3 ). AUDPC values ranged from 41 to 618 , which were lower than values obtained for the susceptible controls, Yungay and Canchan (2036 and 1698 , respectively). Clonal susceptibility scale values ranged from 0.11 to 1.64 , which were lower than values obtained for Yungay and Canchan (4.51 and 5.41, respectively). These values were used to correlate them with values obtained in experiments under controlled conditions (Table 4).

Under controlled conditions, results of combined analysis of variance showed statistically significant differences for environments (E) $(\alpha=0.05)$, clones (C) and isolates (I) $(\alpha=0.01)$ with their respective interactions for AUDPC and sAUDPC values (Table 5 ).

Late blight, as measured by sAUDPC, was significantly more severe under greenhouse conditions than under humidity chamber conditions, (Table 5). Overall average values of sAUDPC obtained by potato clones and controls were $0.76,8.50$ and 0.53 , 8.50 , in the greenhouse and humidity chamber, respectively (Table 6). The average temperature in the greenhouse was $19.63^{\circ}$ $\mathrm{C}$, whereas the average temperature in the humidity chamber was $16.81^{\circ} \mathrm{C}$. Higher temperatures favored disease development.

There were significant differences among the clones for late blight (Table 5). Under greenhouse and humidity chamber conditions, 21 potato clones showed resistance to POX067, PLL69, PPA61 and PPI112 P. infestans isolates (the last three have the Avr9 gene) with average sAUDPC

Table 3 Analysis of variance for AUDPC and sAUDPC values to LB in field experiment. Oxapampa 2018-2019

\begin{tabular}{llll}
\hline Source of Variation & d.f & \multicolumn{2}{l}{ Mean Squares } \\
\cline { 3 - 4 } & & AUDPC $^{\mathrm{a}}$ & sAUDPC $^{\mathrm{c}}$ \\
\hline Replications & 2 & $21314.15 \mathrm{~ns}$ & $0.152 \mathrm{~ns}$ \\
Clones & 23 & $752670.77 * *$ & $5314 * *$ \\
Error & 46 & 5739.78 & 0.041 \\
C.V. \% & & 23.69 & 23.65 \\
\hline
\end{tabular}

$\mathrm{ns}=$ not statistically significant $* *$ statistically significant at $\alpha=0.01$, d.f. $=$ degrees of freedom

${ }^{\mathrm{a}, \mathrm{b}}$ Forbes et al (2014)

${ }^{\mathrm{c}}$ Yuen \& Forbes (2009) 
Table 4 AUDPC and sAUDPC mean values in field experiment, Oxapampa 2018-2019

\begin{tabular}{lll}
\hline Clone & AUDPC $^{\mathrm{a}}$ & sAUDPC $^{\mathrm{b}}$ \\
\hline CIP 308427.194 & 187 & 0.500 \\
CIP 308436.173 & 204 & 0.540 \\
CIP 308436.245 & 222 & 0.590 \\
CIP 308441.148 & 88 & 0.240 \\
CIP 308475.174 & 41 & 0.110 \\
CIP 308478.122 & 175 & 0.460 \\
CIP 308481.302 & 146 & 0.390 \\
CIP 308482.163 & 180 & 0.480 \\
CIP 308487.163 & 82 & 0.220 \\
CIP 308487.390 & 286 & 0.760 \\
CIP 308488.213 & 618 & 1.640 \\
CIP 308489.286 & 99 & 0.270 \\
CIP 308490.407 & 548 & 1.460 \\
CIP 308493.164 & 198 & 0.530 \\
CIP 308494.368 & 53 & 0.140 \\
CIP 308495.329 & 76 & 0.200 \\
CIP 308498.280 & 303 & 0.800 \\
CIP 308499.112 & 53 & 0.140 \\
CIP 308503.312 & 70 & 0.190 \\
CIP 308519.110 & 216 & 0.580 \\
CIP 387164.4 & 47 & 0.120 \\
CIP 393371.58 & 53 & 0.140 \\
Canchan & 1698 & 4.510 \\
Yungay & 2036 & 5.410 \\
\hline & &
\end{tabular}

${ }^{\text {a }}$ Forbes et al. (2014)

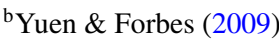

Table 5 Combined analysis of variance over two environments for AUDPC and Scale AUDPC in advanced clones with high levels of resistance to late blight. La Molina 2019

\begin{tabular}{llll}
\hline Source of variation & df & \multicolumn{2}{l}{ Mean Square } \\
\cline { 3 - 4 } & & AUDPC $^{\mathrm{a}}$ & sAUDPC $^{\mathrm{b}}$ \\
\hline Environments (E) & 1 & $4821.61 *$ & $8.91 *$ \\
Replications/E & 6 & $431.54 * *$ & 0.79 \\
Clones (C) & 23 & $21597.20^{* *}$ & $39.60 * *$ \\
Isolates LB (I) & 3 & $12559.11^{* *}$ & $23.20 * *$ \\
C x I & 69 & $1746.26^{* *}$ & $3.21 * *$ \\
C x E & 23 & $1094.03 * *$ & $2.01 * *$ \\
E x I & 3 & $3865.91 * *$ & $7.10 * *$ \\
C x E x I & 69 & $625.38 * *$ & $1.15 * *$ \\
Error pooled & 522 & 14.96 & 0.03 \\
C.V $=\%$ & & 25.41 & 25.48 \\
\hline
\end{tabular}

**Statistically significant at $\alpha=0.01 *$ Statistically significant at $\alpha=0.05$

${ }^{\mathrm{a}}$ Forbes et al. (2014)

${ }^{\mathrm{b}}$ Yuen \& Forbes (2009) values of $0.24,0.17,0.93$ and 1.73 under greenhouse and $0.18,0.18,0.43$ and 1.38 under humidity chamber conditions, respectively. These potato clones maintained their field resistance; however, we hypothesize that these clones have the $R 9$ resistance gene. In contrast, the clone CIP 308488.213 had sAUDPC values of 10.34 and 13.64 for PPI112 and PPA61 in the greenhouse, respectively, and 9.14 for PPA61 in the humid chamber these values were higher even than the susceptible controls Canchan and Yungay. Therefore, CIP 308488.213 was considered susceptible. Controls Yungay and Canchan were highly susceptible to the four isolates (Table 6).

Isolate PPI112 of $P$. infestans was more virulent than the other three isolates both in greenhouse and in humid chamber conditions (Table 6). The PPI112 isolate was collected from $S$. huancabambense and probably has other avirulence genes. PPA61 was the next most virulent isolate.

Although all two-way interactions were highly significant, the most striking from a biological standpoint was the environment $x$ isolate interaction. The PPI112 and PPA61 isolates need higher temperatures for their development. Both isolates were collected in potato producing areas in Peru where the temperatures are higher with respect to the places where the other two isolates were collected. Both the greenhouse and humidity chamber environments strongly favored disease development for PPI112 and PPA61. Neither environment favored disease development for PLL69 and POX67.

\section{Correlation between resistance obtained under field and controlled conditions}

A high correlation was found between resistance of potato clones inoculated with PLL69, POX67 and PPA61 P. infestans isolates under greenhouse conditions and their field resistance with correlation coefficient (r) values of $0.92,0.93$ and 0.80 respectively. Moderate correlation was observed between PPI112 isolate and field resistance with $r$ values of 0.64 .

In the humidity chamber experiment, a high correlation was also found between resistance of potato clones and their resistance in the field when they were inoculated with isolates PLL69, POX67 and PPA61, with $r$ values of 0.93, 0.94 and 0.94 respectively. As in the greenhouses, a moderate correlation was found between the resistance to late blight in a humid chamber and the resistance shown in the field, with $r$ values of 0.77 (Table 7).

Results obtained in this study confirm the field resistance of clones studied under CIP's screening site in Peru (Oxapampa, Pasco), where the presence of the Avr9 gene is absent or its frequency is minimal. With the PPI112 isolate, a moderate correlation was found in both 
Table 6 Susceptibility Scale values (sAUDPC) showed by clones under greenhouse and humidity chamber conditions. La Molina 2019

\begin{tabular}{|c|c|c|c|c|c|c|c|c|c|}
\hline \multirow[t]{3}{*}{ \# } & \multirow[t]{3}{*}{ Clone } & \multicolumn{8}{|c|}{ Susceptibility scale values ${ }^{a}$} \\
\hline & & \multicolumn{4}{|c|}{ Greenhouse } & \multicolumn{4}{|c|}{ Humidity Chamber } \\
\hline & & PLL69 & POX67 & PPA61 & PPI112 & PLL69 & POX67 & PPA61 & PPI112 \\
\hline 1 & CIP 308427.194 & 0.00 & 0.00 & 0.00 & 0.00 & 0.00 & 0.00 & 0.00 & 0.14 \\
\hline 2 & CIP 308436.173 & 0.00 & 0.00 & 0.00 & 0.03 & 0.00 & 0.00 & 0.00 & 0.00 \\
\hline 3 & CIP 308436.245 & 0.00 & 0.00 & 0.00 & 0.03 & 0.00 & 0.00 & 0.00 & 0.42 \\
\hline 4 & CIP 308441.148 & 0.59 & 0.00 & 0.85 & 3.29 & 0.00 & 0.00 & 0.00 & 0.62 \\
\hline 5 & CIP 308475.174 & 0.00 & 0.00 & 0.43 & 1.72 & 0.00 & 0.00 & 0.00 & 0.73 \\
\hline 6 & CIP 308478.122 & 0.00 & 0.04 & 0.06 & 0.00 & 0.00 & 0.00 & 0.00 & 0.69 \\
\hline 7 & CIP 308481.302 & 0.68 & 0.28 & 0.00 & 0.94 & 1.54 & 0.75 & 0.00 & 1.87 \\
\hline 8 & CIP 308482.163 & 0.02 & 1.76 & 0.43 & 0.00 & 0.00 & 0.19 & 0.05 & 0.00 \\
\hline 9 & CIP 308487.163 & 0.00 & 0.00 & 0.02 & 0.00 & 0.00 & 0.00 & 0.68 & 0.00 \\
\hline 10 & CIP 308487.390 & 0.00 & 0.04 & 1.24 & 2.67 & 0.39 & 0.98 & 0.90 & 3.67 \\
\hline 11 & CIP 308488.213 & 0.00 & 0.11 & 10.34 & 13.64 & 0.00 & 0.02 & 2.47 & 9.14 \\
\hline 12 & CIP 308489.286 & 0.00 & 0.00 & 0.02 & 0.47 & 0.00 & 0.00 & 0.00 & 0.21 \\
\hline 13 & CIP 308490.407 & 0.39 & 0.00 & 0.64 & 0.63 & 0.39 & 0.38 & 0.82 & 1.32 \\
\hline 14 & CIP 308493.164 & 0.59 & 0.00 & 0.02 & 0.06 & 0.05 & 0.19 & 0.00 & 1.11 \\
\hline 15 & CIP 308494.368 & 1.04 & 0.71 & 1.45 & 3.76 & 0.00 & 0.19 & 0.05 & 2.66 \\
\hline 16 & CIP 308495.329 & 0.39 & 0.71 & 1.45 & 2.98 & 0.39 & 0.02 & 0.03 & 0.83 \\
\hline 17 & CIP 308498.280 & 0.00 & 0.00 & 0.00 & 0.00 & 0.00 & 0.00 & 0.00 & 0.00 \\
\hline 18 & CIP 308499.112 & 0.04 & 0.00 & 0.00 & 0.06 & 0.00 & 0.00 & 1.23 & 0.28 \\
\hline 19 & CIP 308503.312 & 0.00 & 0.00 & 0.00 & 0.00 & 0.00 & 0.00 & 0.00 & 0.00 \\
\hline 20 & CIP 308519.110 & 0.00 & 0.00 & 1.55 & 3.14 & 0.00 & 0.00 & 0.82 & 2.01 \\
\hline 21 & CIP 387164.4 & 0.37 & 0.04 & 0.00 & 0.63 & 0.00 & 0.00 & 1.45 & 0.01 \\
\hline \multirow[t]{3}{*}{22} & CIP 393371.58 & 1.17 & 0.00 & 1.86 & 3.92 & 1.29 & 1.22 & 0.95 & 4.71 \\
\hline & Overall average Isolates & 0.24 & 0.17 & 0.93 & 1.73 & 0.18 & 0.18 & 0.43 & 1.38 \\
\hline & Overall average Clones & 0.76 & & & & 0.53 & & & \\
\hline 23 & Canchan & 9.00 & 9.00 & 9.00 & 9.00 & 9.00 & 9.00 & 9.00 & 9.00 \\
\hline \multirow[t]{2}{*}{24} & Yungay & 8.00 & 8.00 & 8.00 & 8.00 & 8.00 & 8.00 & 8.00 & 8.00 \\
\hline & Overall average controls & 8.50 & & & & 8.50 & & & \\
\hline
\end{tabular}

${ }^{\text {a }}$ Yuen \& Forbes (2009)

Resistant: clones with scale value between 0 to 3; moderately resistant: clones with scale value between 3.1 to 6 , and susceptible: clones with scale value between 6.1 to 9

Table 7 Pearson's correlation coefficients (r) for LB resistance (sAUDPC), between greenhouse and humid chamber conditions with resistance to LB under field

\begin{tabular}{|c|c|c|c|c|c|c|c|c|c|c|}
\hline \multirow[t]{3}{*}{ Environment } & \multirow[t]{3}{*}{ LB Isolate } & \multicolumn{9}{|c|}{ Pearson Correlation Coefficients } \\
\hline & & \multicolumn{4}{|c|}{ Greenhouse } & \multicolumn{4}{|c|}{ Humid Chamber } & \multirow[t]{2}{*}{ Field } \\
\hline & & PLL69 & POX67 & PPA61 & PPI112 & PLL69 & POX67 & PPA61 & PPI112 & \\
\hline \multirow[t]{4}{*}{ Greenhouse } & PLL69 & & 0.98 & 0.71 & 0.57 & 0.99 & 0.99 & 0.95 & 0.72 & 0.92 \\
\hline & POX67 & & & 0.71 & 0.55 & 0.97 & 0.98 & 0.94 & 0.68 & 0.93 \\
\hline & PPA61 & & & & 0.96 & 0.70 & 0.71 & 0.82 & 0.95 & 0.80 \\
\hline & PPI112 & & & & & 0.56 & 0.56 & 0.68 & 0.93 & 0.64 \\
\hline \multirow[t]{4}{*}{ Humid Chamber } & PLL69 & & & & & & 1.00 & 0.95 & 0.73 & 0.93 \\
\hline & POX67 & & & & & & & 0.96 & 0.74 & 0.94 \\
\hline & PPA61 & & & & & & & & 0.81 & 0.94 \\
\hline & PPI112 & & & & & & & & & 0.77 \\
\hline
\end{tabular}


Table 8 Analysis of variance on area under the disease progress curve (AUDPC) by environment

\begin{tabular}{lllll}
\hline Source of variation & d.f & Mean Squares & \\
\cline { 3 - 5 } & & Greenhouse & Humidity Chamber & Field \\
\hline Replications & 3 & $10.273 \mathrm{~ns}$ & $7.351 \mathrm{~ns}$ & $21314.15 \mathrm{~ns}$ \\
Clones & 23 & $2077.523 * *$ & $3825.481 * *$ & $752670.77 * *$ \\
Error & 69 & 2.803 & 3.547 & 5739.78 \\
Coefficient of variation & & 13.09 & 11.07 & 23.69 \\
\hline
\end{tabular}

$\mathrm{ns}=$ not statistically significant $* *$ statistically significant at $\alpha=0.01$, d.f. $=$ degrees of freedom experiments, probably due to the presence of unknown avirulence genes in this isolate, as was hypothesized above. It is recommended to evaluate resistance of potato clones by inoculating them with isolates from other hosts, such as wild Solanum species, to expand the knowledge of pathogen-host interaction.

Twenty-one potato clones studied showed resistance to the four isolates used, confirming that selection carried out under field conditions in Oxapampa identified clones with high levels of resistance to LB under high pressure of isolates with the Avr9 gene under controlled conditions.

\section{Phenotypic stability of late blight resistance under controlled conditions.}

Analysis of individual variance for AUDPC in the three environments, showed statistically significant differences $(\alpha=0.01)$ for clones studied. The coefficients of variation (CV) in the experiments under greenhouse, humidity chamber and field conditions were $13.09 \%, 11.07 \%$ and $23.69 \%$, respectively. The higher $\mathrm{CV}$ under field conditions was to be expected because presumably there were more sources of experimental variability under field conditions than under the more controlled greenhouse and humidity chamber conditions. Error variances for greenhouse, humidity
Table 9 Mean area under the disease progress curve (AUDPC) and rankings of AUDPC (Rank) for 22 potato clones and two controls, in three environments (greenhouse, humidity chamber and field)

\begin{tabular}{|c|c|c|c|c|c|c|c|}
\hline \multirow[t]{2}{*}{ \# } & \multirow[t]{2}{*}{ Clone } & \multicolumn{6}{|l|}{ AUDPC } \\
\hline & & Greenhouse & Rank & $\begin{array}{l}\text { Humidity } \\
\text { Chamber }\end{array}$ & Rank & Field & Rank \\
\hline 1 & CIP 308427.194 & 0.00 & 1 & 0.31 & 2 & 187.00 & 13 \\
\hline 2 & CIP 308436.173 & 0.06 & 2 & 0.00 & 1 & 204.00 & 15 \\
\hline 3 & CIP 308436.245 & 0.06 & 2 & 1.88 & 5 & 222.00 & 17 \\
\hline 4 & CIP 308441.148 & 11.00 & 13 & 2.81 & 7 & 88.00 & 8 \\
\hline 5 & CIP 308475.174 & 4.75 & 10 & 3.31 & 9 & 41.00 & 1 \\
\hline 6 & CIP 308481.302 & 4.25 & 7 & 15.94 & 17 & 175.00 & 11 \\
\hline 7 & CIP 308482.163 & 4.50 & 9 & 0.75 & 3 & 146.00 & 10 \\
\hline 8 & CIP 308487.163 & 0.06 & 2 & 2.19 & 6 & 180.00 & 12 \\
\hline 9 & CIP 308487.390 & 9.13 & 11 & 23.75 & 18 & 82.00 & 7 \\
\hline 10 & CIP 308488.213 & 58.63 & 18 & 48.85 & 20 & 286.00 & 18 \\
\hline 11 & CIP 308489.286 & 1.00 & 4 & 0.94 & 4 & 618.00 & 21 \\
\hline 12 & CIP 308490.407 & 4.44 & 8 & 10.94 & 14 & 99.00 & 9 \\
\hline 13 & CIP 308493.164 & 2.06 & 5 & 5.75 & 13 & 548.00 & 20 \\
\hline 14 & CIP 308494.368 & 16.44 & 15 & 12.75 & 16 & 198.00 & 14 \\
\hline 15 & CIP 308495.329 & 12.81 & 14 & 5.13 & 12 & 53.00 & 3 \\
\hline 16 & CIP 308498.280 & 0.00 & 1 & 0.00 & 1 & 76.00 & 6 \\
\hline 17 & CIP 308499.112 & 0.25 & 3 & 5.00 & 11 & 303.00 & 19 \\
\hline 18 & CIP 308503.312 & 0.00 & 1 & 0.00 & 1 & 53.00 & 3 \\
\hline 19 & CIP 308519.110 & 10.94 & 12 & 11.56 & 15 & 70.00 & 5 \\
\hline 20 & CIP 38478.122 & 0.25 & 3 & 3.13 & 8 & 216.00 & 16 \\
\hline 21 & CIP 387164.4 & 2.50 & 6 & 4.50 & 10 & 47.00 & 2 \\
\hline 22 & CIP 393371.58 & 17.19 & 16 & 32.19 & 19 & 53.00 & 4 \\
\hline 23 & Canchan & 89.81 & 19 & 126.88 & 22 & $1,698.00$ & 22 \\
\hline 24 & Yungay & 56.75 & 17 & 89.69 & 21 & $2,036.00$ & 23 \\
\hline
\end{tabular}


chamber and field were $2.803,3.547$ and 2739.78 respectively (Table 8 ). Bartlett's test of homogeneity of variances was significant, with a calculated $\chi 2=112.08(\mathrm{P}<0.05)$ indicating that there was no homoscedasticity among the three environments. Therefore, the phenotypic stability was analyzed using a non-parametric test.

AUDPC values obtained by twenty-two potato clones and two controls ranged from 0 to 89.81 under greenhouse conditions, 0 to 126.88 in humid chamber and from 187 to 2036 under field conditions (Table 9) All potato clones, with the one exception of CIP 308,488.213 in the greenhouse, presented AUDPC values lower than the controls, demonstrating their resistance to LB.

Nonparametric statistics developed by Huehn (1990a, b), namely $\mathrm{S} 1$, which measures the absolute mean ranks differences of a clone over all locations, and S2, which measures the common variance of the ranks, are tested with two Z-statistics, Z1 and Z2, which are measures of stability. Although the sum of the $Z_{1}$ s was significant, none of the individual $Z_{1}$ statistics was significant (Table 10), indicating that the resistance to late blight in the clones studied measured through the rankings of the means of their AUDPC, were phenotypically stable across these three environments. Even the three clones that made the largest contribution to the overall sum of the Z1s, CIP308487.163, CIP393371.58 and Yungay, were rated stable across environments.

The environment is very important in the development of this disease. In the field test, there were ideal conditions of temperature, precipitation, and relative humidity for the development of a high disease pressure from the pathogen. Also, in the tests under controlled conditions, the temperature and relative humidity were optimal to achieve a high disease pressure of the pathogen. Non-parametric phenotypic stability analysis allows us to eliminate the variations among environments, the intervals of the evaluations, etc., which cause heterogeneity of the error variances among the environments and does not allow us to comply with the statistical assumptions necessary for a parametric analysis.

The phenotypic stability shown by the clones is probably indicating that the clones have the $R 9$ resistance gene to confront the $A v r 9$ gene present in the greenhouse and humid chamber tests.
Table 10 Mean area under disease progress curve (AUDPC), mean of the absolute rank differences of a clone (S1) and its approximate test of significance (Z1) and common variance of the ranks (S2) and its approximate test of significance (Z2) across environments

\begin{tabular}{|c|c|c|c|c|c|c|c|}
\hline \# & Clone & Mean AUDPC & Mean Rank & S1 & $\mathrm{Z} 1$ & $\mathrm{~S} 2$ & $\mathrm{Z} 2$ \\
\hline 1 & CIP 308427.194 & 62.44 & 12.00 & 3.33 & 1.67 & 7.00 & 0.00 \\
\hline 2 & CIP 308436.173 & 68.02 & 11.33 & 4.67 & 0.85 & 16.33 & 0.01 \\
\hline 3 & CIP 308436.245 & 74.65 & 10.33 & 8.00 & 0.00 & 44.33 & 0.30 \\
\hline 4 & CIP 308441.148 & 33.94 & 14.00 & 6.00 & 0.30 & 21.00 & 0.04 \\
\hline 5 & CIP 308475.174 & 16.35 & 16.00 & 14.00 & 2.79 & 147.00 & 4.49 \\
\hline 6 & CIP 308481.302 & 65.06 & 12.33 & 2.00 & 2.77 & 2.33 & 0.01 \\
\hline 7 & CIP 308482.163 & 50.42 & 12.67 & 2.00 & 2.77 & 2.33 & 0.01 \\
\hline 8 & CIP 308487.163 & 60.75 & 12.33 & 0.67 & 4.14 & 0.33 & 0.01 \\
\hline 9 & CIP 308487.390 & 38.29 & 14.67 & 9.33 & 0.14 & 50.33 & 0.41 \\
\hline 10 & CIP 308488.213 & 131.16 & 11.00 & 8.67 & 0.04 & 49.00 & 0.39 \\
\hline 11 & CIP 308489.286 & 206.65 & 9.33 & 12.67 & 1.69 & 120.33 & 2.93 \\
\hline 12 & CIP 308490.407 & 38.13 & 13.67 & 4.00 & 1.23 & 10.33 & 0.00 \\
\hline 13 & CIP 308493.164 & 185.27 & 9.67 & 11.33 & 0.86 & 96.33 & 1.81 \\
\hline 14 & CIP 308494.368 & 75.73 & 12.33 & 2.67 & 2.18 & 4.33 & 0.00 \\
\hline 15 & CIP 308495.329 & 23.65 & 15.67 & 13.33 & 2.21 & 108.33 & 2.34 \\
\hline 16 & CIP 308498.280 & 25.33 & 14.00 & 6.00 & 0.30 & 27.00 & 0.08 \\
\hline 17 & CIP 308499.112 & 102.75 & 10.00 & 10.00 & 0.31 & 75.00 & 1.04 \\
\hline 18 & CIP 308503.312 & 17.67 & 15.00 & 10.00 & 0.31 & 75.00 & 1.04 \\
\hline 19 & CIP 308519.110 & 30.83 & 14.33 & 8.67 & 0.04 & 52.33 & 0.45 \\
\hline 20 & CIP 38478.122 & 73.13 & 10.67 & 6.67 & 0.13 & 30.33 & 0.11 \\
\hline 21 & CIP 387164.4 & 18.00 & 15.67 & 12.67 & 1.69 & 120.33 & 2.93 \\
\hline 22 & CIP 393371.58 & 34.13 & 15.33 & 15.33 & 4.17 & 156.33 & 5.11 \\
\hline 23 & Canchan & 638.23 & 9.00 & 14.00 & 2.79 & 147.00 & 4.49 \\
\hline \multirow[t]{2}{*}{24} & Yungay & 727.48 & 8.67 & 15.33 & 4.17 & 176.33 & 6.59 \\
\hline & Sum of $\mathrm{Zi}$ & & & & 37.55 & & 34.60 \\
\hline
\end{tabular}

The Z-statistics are measures of stability. The tests for the significance of the sum of Z1 or Z2 are compared to a $\chi^{2}$ value of 36.42 . Individual $Z 1$ or $Z 2$ are compared to a $\chi^{2}$ value of 9.48 
Potato clones with stable resistance can be used as parents in breeding programs to develop new varieties. However, based on the results in this paper we recommend including several $P$. infestans isolates in the resistance assays. Likewise, non-parametric analysis eliminates the restrictions of parametric analysis and provides a powerful tool for analyzing the importance of genotype $\mathrm{x}$ environment interactions when heterogeneous error variances among environments do not allow for parametric data analysis.

Acknowledgements This research was undertaken as part of, and funded by, the CGIAR Research Program on Roots, Tubers and Bananas (RTB) and by USAID, supported by CGIAR through the CGIAR Trust Fund Donors (https://www.cgiar.org/funders/). We are thankful for the technical collaboration of F. Ventura, E. De la Torre, Y. Correa and P. Rojas in greenhouse and laboratory activities.

\section{Declarations}

Conflicts of Interest The authors do not have any conflict of interest.

Open Access This article is licensed under a Creative Commons Attribution 4.0 International License, which permits use, sharing, adaptation, distribution and reproduction in any medium or format, as long as you give appropriate credit to the original author(s) and the source, provide a link to the Creative Commons licence, and indicate if changes were made. The images or other third party material in this article are included in the article's Creative Commons licence, unless indicated otherwise in a credit line to the material. If material is not included in the article's Creative Commons licence and your intended use is not permitted by statutory regulation or exceeds the permitted use, you will need to obtain permission directly from the copyright holder. To view a copy of this licence, visit http://creativecommons.org/licenses/by/4.0/.

\section{References}

Bartlett, M.S. 1937. Some examples of statistical methods of research in agriculture and applied biology. J. Royal Statist. Soc. Suppl. 4: $137-170$.

Black, W., C. Mastenbroek, W.R. Mills, and L.C. Peterson. 1953. A proposal for an international nomenclature of races of Phytophthora infestans and of genes controlling immunity in Solanum demissum derivatives. Euphytica 2:173-178.

Cárdenas M, Grajales A, Sierra R, Rojas A, González-Almario A, Vargas A, Marín M, Fermín G, Lagos LE, Grünwald NJ, Bernal A, Salazar C, Restrepo S. Genetic diversity of Phytophthora infestans in the Northern Andean region. BMC Genet. 2011 Feb 9;12:23. https://doi.org/10.1186/1471-2156-12-23

Delgado RA, Monteros-Altamirano AR, Li Y, Visser RGF, van der Lee TAJ, Vosman B, 2013. Large subclonal variation in Phytophthora infestans populations associated with Ecuadorian potato landraces. Plant Pathology 62, 1081-8.

Devaux, A., P. Kroman, and O. Ortiz. 2014. Potatoes for Sustainable Global Food Security. Potato Research 57: 185-199. https://doi. org/10.1007/s11540-014-9265-1.

Dorrance, A.E., and D.A. Inglis. 1997. Assessment of Greenhouse and Laboratory Screening Methods for Evaluating Potato Foliage for Resistance to Late Blight. Plant Disease 81 (10): 1206-1213.
Flor, H.H. 1971. Current status of the gene-for-gene concept. Annual Review of Phytopathology 9: 275-296.

Forbes, G.A., M.G. Chacón, H.G. Kirk, M.A. Huarte, M. Van Damme, S. Distel, G.R. Mackay, H.E. Stewart, R. Lowe, J.M. Duncan, H.S. Mayton, W.E. Fry, D. Andrivon, D. Ellissèche, R. Pellé, H.W. Platt, G. MacKenzie, T.R. Tarn, L.T. Colón, D.J. Budding, H. LozoyaSaldaña, A. Hernandez-Vilchis, and S. Capezio. 2005. Stability of resistance to Phytophthora infestans in potato: An international evaluation. Plant Pathology. 54: 364-372.

Forbes, G.; Pérez, W.; Andrade Piedra, J. 2014. Field assessment of resistance in potato to Phytophthora infestans. Lima (Peru). International Potato Center (CIP). $35 \mathrm{p}$

Forbes, G.A. 2012. Using host resistance to manage potato late blight with particular reference to developing countries. Potato Research 55: 205-216.

Fraser D.A.S. 1992 Introduction to Bartlett (1937) Properties of Sufficiency and Statistical Tests. In: Kotz S.. Johnson N.L. (eds) Breakthroughs in Statistics. Springer Series in Statistics (Perspectives in Statistics). Springer. New York. NY. https://doi.org/ 10.1007/978-1-4612-0919-5 7

Haynes, K.G., D.H. Lambert, B.J.D.P. Christ, D.S. Weingartner, J.E. Douches, G. Backhmd, W. Fry. Secor, and W. Stevenson. 1998. Phenotypic stability of resistance to late blight in potato clones evaluated at eight sites in the United States. Am. J. Pot Res 75: 211-217. https://doi.org/10.1007/BF02854215.

Huehn, M. 1990a. Nonparametric measures of phenotypic stability. Part 1:Theory. Euphytica 47: 189-194.

Huehn, M. 1990b. Nonparametric measures of phenotypic stability. Part 2: Applications. Euphytica 47: 195-201.

Jiang, R., J. Li, Z. Tian, J. Du, M. Armstrong, K. Baker, J. Tze-Yin Lim, J.H. Vossen, H. He, L. Portal, and J. Zhou. 2018. Potato late blight field resistance from QTL dPI09c is conferred by the NB-LRR gene R8. Journal of Experimental Botany 69 (7): $1545-1555$.

Landeo, J. A., M. Gastelo, H. Pinedo, and F. Flores. 1995. "Breeding for Horizontal Resistance to Late Blight in Potato Free of $\mathrm{R}$ Genes." In Phytophthora Infestans 150, 268-74. Dublin: Boole Press.

Landeo, J., M. Gastelo, G. Forbes, J. L. Zapata, and Flores F.J. 1997. "Developing Horizontal Resistance to Late Blight in Potato." Lima, Peru: International Potato Center (CIP).

Leon, J., and H.C. Becker. 1988. Repeatability of some statistical measures of phenotypic stability - correlations between single year results and multi years results. Plant Breeding 100: 137-142.

Li Y, Van der Lee TAJ, Evenhuis A, van den Bosch GBM, van Bekkum PJ, Förch MG, et al. Population dynamics of Phytophthora infestans in the Netherlands reveals expansion and spread of dominant clonal lineages and virulence in sexual offspring. G3. 2012;2: 1529-40.

Lindqvist-Kreuze, H., Gamboa, S., Izarra, M., Pérez, W., Correa, M.Y., Astete, A., Särkinen, T., Cueva, M. and Gonzáles, P. 2020, Population structure and host range of the potato late blight pathogen Phytophthora infestans in Peru spanning two decades. Plant Pathol, 69: 334-346. https://doi.org/10.1111/ppa.13125

Lindqvist-Kreuze H, Gastelo M, Perez W, Forbes GA, de Koeyer D, Bonierbale M. 2014 Phenotypic stability and genome-wide association study of late blight resistance in potato genotypes adapted to the tropical highlands. Phytopathology. 2014 Vol. 104, No. 6, 2014, 624-633. https://doi.org/10.1094/PHYTO-10-13-0270-R

Lindqvist-Kreuze, H., D. Carbajulca, G. Gonzalez-Escobedo, W. Pérez, and M. Bonierbale. 2010. Comparison of transcript profiles in late blight-challenged Solanum cajamarquense and $\mathrm{B} 3 \mathrm{C} 1$ potato clones. Molecular Plant Pathology 11 (4): 513-530. https://doi. org/10.1111/j.1364-3703.2010.00622.x. 
Lotta, Kaila. 2015. "Inheritance and Stability of Late Blight Resistance in Potato Population B3 of the International Potato Center." Helsinki, Finland: University of Helsinki, Faculty of Agriculture and Forestry, Department of Agricultural Sciences. http://urn.fi/ URN:NBN:fi:hulib-201509013571

Lu, H.Y. 1995. PC-SAS Program for Estimating Hühn's Nonparametric Stability Statistics. Agronomy Journal 87: 888-891. https://doi. org/10.2134/agronj1995.00021962008700050018x.

Malcolmson, J.F., and W. Black. 1966. New R-genes in Solanum demissum Lindl. and their complementary races of Phytophthora infestans (Mont.) de Bary. Euphytica 15: 199-203.

Mihovilovich, E., S. Munive, and M. Bonierbale. 2010. Influence of Day-Length and Isolates of Phytophthora Infestans on Field Resistance to Late Blight of Potato. Theoretical and Applied Genetics 120 (6): 1265-1278. https://doi.org/10.1007/ s00122-009-1254-4.

Nassar, R., and M. Huhn. 1987. Studies on estimation of phenotypic stability: Tests of significance for nonparametric measures of phenotypic stability. Biometrics 43: 45-53.

Neter. J. and W. Wasserman. 1974. Applied linear statistical models: regression. analysis of variance. and experimental design.

Nutter F W Jr, P S Teng, M H Royer (1993) Terms and concepts for yield, crop loss, and disease thresholds. Plant Dis. 77:211-215.

Pérez, W., Lara, J. \& Forbes, G.A. Resistance to metalaxyl-M and cymoxanil in a dominant clonal lineage of Phytophthora infestans in Huánuco, Peru, an area of continuous potato production. Eur J Plant Pathol 125, 87-95 (2009). https://doi.org/10. 1007/s10658-009-9461-z

Sharma, Buddhi P., Gregory A. Forbes, Hira K. Manandhar, Sundar M. Shrestha, and Resham B. Thapa. 2013. Determination of
Resistance to Phytophthora Infestans on Potato Plants in Field, Laboratory and Greenhouse Conditions. Journal of Agricultural Science 5 (5): 148-57. https://doi.org/10.5539/jas.v5n5p148.

Simmonds, N.W., and R.L. Wastie. 1987. Assessment of horizontal resistance to late blight of potatoes. The Annals of Applied Biology 111: 213-221.

Umaerus, V., and Umaerus, M. 1994. Inheritance of resistance to late blight. Pages 365-401 in: Potato Genetics. J. E. Bradshaw and G. R. Mackay, eds. CAB International, Wallingford, UK.

Villamon, F.G., D.M. Spooner, M. Orrillo, E. Mihovilovich, W. Pérez, and M. Bonierbale. 2005. Late blight resistance linkages in a novel cross of the wild potato species Solanum paucissectum (series Piurana). TAG. Theoretical and Applied Genetics. 111: 1201-1214.

Vleeshouwers, Vgaa, W. van Dooijeweert, L.C.P. Keizer, L. Sijpkes, F. Govers, L.T. Colon, and W. van Dooijeweert. 1999. A Laboratory Assay for Phytophthora Infestans Resistance in Various Solanum Species Reflects the Field Situation. European Journal of Plant Pathology 105 (3): 241-250.

Wang J. (2013) Pearson Correlation Coefficient. In: Dubitzky W., Wolkenhauer O., Cho KH., Yokota H. (eds) Encyclopedia of Systems Biology. Springer, New York, NY. https://doi.org/10.1007/ 978-1-4419-9863-7_372

Yuen JE and Forbes GA.2009 Estimating the level of susceptibility to Phytophthora infestans in potato genotypes. Phytopathology. 2009 Jun;99(6):782-6. doi: https://doi.org/10.1094/PHYTO-99-6-0782. PMID: 19453239. 